\title{
Haemostatic clips in the management of an acute gastrointestinal bleed from a Dieulafoy lesion
}

\author{
Tallal Hussain, ${ }^{1,2}$ Azhar Hafeez, ${ }^{2}$ Adam Nicholls, ${ }^{3}$ Jonathan Sutcliffe ${ }^{4}$
}

'Paediatric Intensive Care Unit (L47), Leeds Teaching Hospitals NHS Trust, Leeds, UK

2Department of Paediatrics, Bradford Teaching Hospitals NHS Foundation Trust, Bradford, UK

${ }^{3}$ Paediatric Intensive Care Unit, Manchester University NHS Foundation Trust, Manchester, UK

${ }^{4}$ Paediatric Surgery, Leeds General Infirmary, Leeds, UK

\section{Correspondence to}

Dr Tallal Hussain:

Tallal.Hussain@nhs.net

Accepted 20 February 2021

\section{DESCRIPTION}

A 5-year-old boy had three large episodes of melaena and presented to the Accident and Emergency Department in hypovolaemic shock (heart rate $180 \mathrm{bpm}$, blood pressure 70/40 and haemoglobin $54 \mathrm{~g} / \mathrm{L})$. He required $60 \mathrm{~mL} / \mathrm{kg}$ of $0.9 \%$ sodium chloride, $60 \mathrm{~mL} / \mathrm{kg}$ of packed red cells, $30 \mathrm{~mL} / \mathrm{kg}$ of fresh frozen plasma and $15 \mathrm{~mL} / \mathrm{kg}$ of platelets and was taken to theatre for an upper gastrointestinal (GI) endoscopy. A Dieulafoy lesion with a large clot was noted in the stomach. This was successfully controlled with dual therapy using epinephrine injection and the application of three haemostatic clips (figure 1). Six months later the patient was followed up with repeat endoscopy; the lesions had healed and the clips were no longer present.

Dieulafoy lesions are extremely rare in children. ${ }^{1}$ They are caused by abnormally large superficial arteries with a mucosal defect that are eroded into and present with severe, painless GI bleeding, which may be recurrent. Unlike adults, lesions in children are thought to be congenital in nature. Dieulafoy

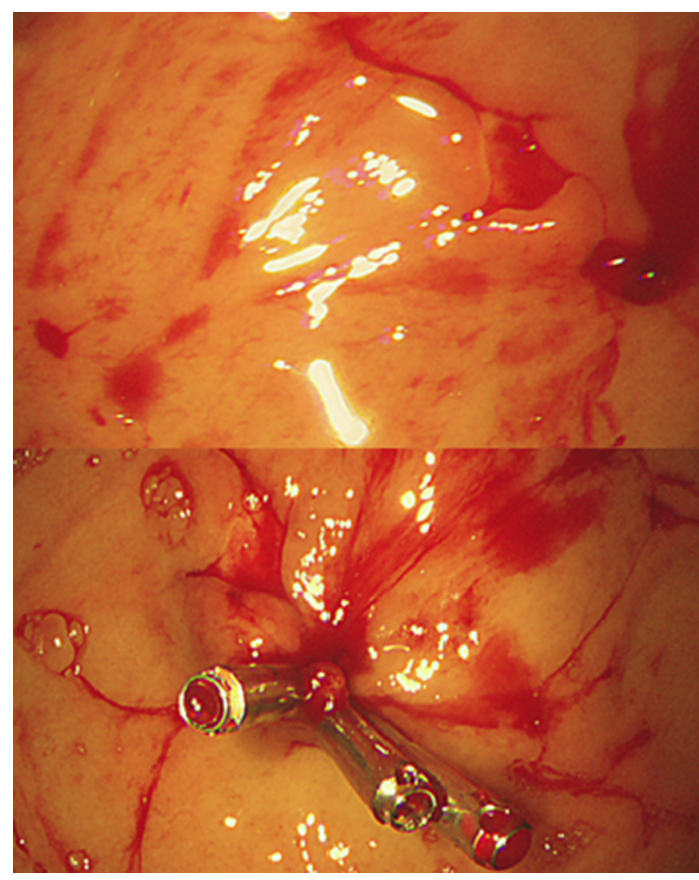

Figure 1 Esophagogastroduodenoscopy revealed an actively oozing, dark red, raised lesion without surrounding erosions or ulceration along the greater curvature characteristic of a Dieulafoy lesion (top). The bleeding was successfully controlled using dual therapy with injection of epinephrine and the application of three haemostatic clips (bottom).

\section{Learning points}

- Although rare, Dieulafoy lesions are an important cause of gastrointestinal (GI) bleeds that can lead to massive haemorrhages.

- There are different management approaches to Dieulafoy lesions with evidence of combination therapy, haemostatic clips and band ligation being the most effective.

- The presence of haemostatic clips is not a contraindication for the insertion of nasogastric feeding tube.

- Haemostatic clips may pass out of the GI system by themselves and do not require further intervention.

lesions have a male predominance $(2: 1){ }^{2}$ They are mainly found along the lesser curvature of the stomach, although they can be found along the GI tract and have also been found in the tracheobronchial tree. ${ }^{3}$ The pathogenesis is largely unknown.

Endoscopic diagnosis is the gold standard. ${ }^{3}$ However, if endoscopy fails to identify a bleeding point, or if the lesion is at an obscure location, angiography can also be diagnostic, and will show contrast enter the GI system from the erosion. ${ }^{4}$

There are a variety of management techniques used for bleeding Dieulafoy lesions including endoscopic, endovascular and surgical intervention. The choice of intervention depends on the location of the lesion, the resources available and the clinical status of the patient. Haemostatic clips and endoscopic band ligation have been shown to be superior to other endoscopic methods with less rebleeding rates. ${ }^{5}$ Furthermore, monotherapy has been shown to have a higher rebleeding rate compared with combination therapy. ${ }^{6}$ The presence of haemostatic clips is not a contraindication for the insertion of nasogastric feeding tube. This case also demonstrates how haemostatic clips may pass out of the GI system by themselves and do not require further intervention.

Contributors $\mathrm{TH}, \mathrm{AH}, \mathrm{AN}$ and JS have all been equally involved in the design, writing and review of the manuscript.

Funding The authors have not declared a specific grant for this research from any funding agency in the public, commercial or not-for-profit sectors.

Competing interests None declared.

Patient consent for publication Obtained.

Provenance and peer review Not commissioned; externally peer reviewed. 
Images in...

\section{REFERENCES}

1 Lim W, Kim TO, Park SB, et al. Endoscopic treatment of Dieulafoy lesions and risk factors for rebleeding. Korean J Intern Med 2009;24:318-22.

2 Itani M, Alsaied T, Charafeddine L, et al. Dieulafoy's lesion in children. J Pediatr Gastroenterol Nutr 2010;51:672-4.

3 Senger JL, Kanthan R. The evolution of Dieulafoy's lesion since 1897: then and now journey through the lens of a paediatric lesion with literature review. Gastroenterol Res Pract 2012
4 Alshumrani G, Almuaikeel M. Angiographic findings and endovascular embolization in Dieulafoy disease: a case report and literature review. Diagn Interv Radiol 2006:12:151-4.

5 Alis $\mathrm{H}$, Oner OZ, Kalayci MU, et al. Is endoscopic band ligation superior to injection therapy for Dieulafoy lesion? Surg Endosc 2009;23:1465-9.

6 Baxter M, Aly EH. Dieulafoy's lesion: current trends in diagnosis and management. Ann $R$ Coll Surg Engl 2010;92:548-54.

Copyright 2021 BMJ Publishing Group. All rights reserved. For permission to reuse any of this content visit

https://www.bmj.com/company/products-services/rights-and-licensing/permissions/

BMJ Case Report Fellows may re-use this article for personal use and teaching without any further permission.

Become a Fellow of BMJ Case Reports today and you can:

- Submit as many cases as you like

- Enjoy fast sympathetic peer review and rapid publication of accepted articles

- Access all the published articles

Re-use any of the published material for personal use and teaching without further permission

Customer Service

If you have any further queries about your subscription, please contact our customer services team on +44 (0) 2071111105 or via email at support@bmj.com.

Visit casereports.bmj.com for more articles like this and to become a Fellow 